\title{
Production of Sugar Beet Pulp/LDPE Composites Using Compression Molding Method and Investigation of Some Properties
}

\author{
Yıldız BİRBİLEN* • Kadir KARAKUŞ @ , Fatih MENGELOĞLU @ \\ Kahramanmaraş Sütçü İmam University, Faculty of Forestry, Department of Forest Industrial \\ Engineering, Kahramanmaraş, TURKEY \\ *Corresponding Author:yildizbrbln@gmail.com
}

Received Date: 14.06.2021

Accepted Date: 18.10 .2021

\section{Abstract}

Aim of study: In this study, the effect of lignocellulosic filler and coupling agent amount on the physical and mechanical properties of produced sugar beet pulp/LDPE composites were researched.

Material and methods: Wood-plastic composites were produced using compression molding method. The effect of lignocellulosic filler and coupling agent (maleic anhydride grafted polyethylene) amount on the physical (density and water uptake analyses) and mechanical (tensile strength, tensile modulus, elongation at break, flexural strength, flexural modulus, and impact strength) properties of composites were investigated.

Main results: According to the obtained results, the rise in the amount of SBP were increased the density, tensile modulus, flexural strength, and flexural modulus while decreasing tensile strength, elongation at break, and impact strength of the resulting composites. Generally, the increase of coupling agent (MAPE) amount improved the composites properties except for impact strength and elongation at break.

Highlights: Sugar beet pulp (SBP) can be successfully used as an alternative lignocellulosic filler in the wood plastic composite production.

Keywords: Wood Plastic Composite, Sugar Beet Pulp, Compression Molding, Mechanical Properties

Pres Kalıplama Yöntemi Kullanılarak Şeker Pancarı
Küspesi/LDPE Kompozitlerin Üretilmesi ve Bazı Özelliklerinin
İncelenmesi

Öz

Çalışmanın amacı: Bu çalışmada, üretilen şeker pancarı küspesi/LDPE kompozitlerin fiziksel ve mekanik özellikleri üzerine lignoselülozik dolgu maddesi ve uyumlaştırıcı ajan miktarının etkisi araştırılmıştır.

Materyal ve yöntem: Kompozitlerin fiziksel (yoğunluk ve su alma analizleri) ve mekanik (çekme direnci, çekmede elastikiyet modülü, kopmada uzama, eğilme direnci, eğilmede elastikiyet modülü ve darbe direnci) özellikleri üzerine dolgu maddesi ve uyumlaştırıcı ajan miktarının etkisi incelenmiştir.

Temel sonuçlar: Elde edilen sonuçlara göre, şeker pancarı küspesi miktarındaki artışlar yoğunluk, çekmede elastikiyet modülü, eğilme direnci ve eğilmede elastikiyet modülü değerlerini artırmıştır. Çekme direnci, kopmada uzama ve darbe direnci şeker pancarı küspesi oranının artması ile azalmıştır. Uyumlaştırıcı ajan MAPE miktarının artması ise kopmada uzama ve darbe direnci hariç genel olarak kompozitlerin özelliklerini iyileştirmiştir.

Araştırma vurguları: Şeker pancarı küspesinin odun plastik kompozit üretiminde alternatif bir lignoselülozik dolgu maddesi olarak kullanılabileceği belirlenmiştir.

Anahtar kelimeler: Odun Plastik Kompozit, Şeker Pancarı Küspesi, Pres Kalıplama, Mekanik Özellikler. 


\section{Introduction}

Wood plastic composites (WPCs) fundamentally are obtained by combining thermoplastic polymers and lignocellulosic materials. There are many advantages of wood plastic composites including having low cost, lightweight, durability against chemicals and corrosion, recyclability, process ability, high dimensional stability. These advantages result in an increased utilization of lignocellulosic materials in WPCs (Mengeloglu \& Cavus, 2019). They are used in many areas such as floor covering, outdoor furniture, marine, decking, automobile parts, and door and window frames (Mengeloglu \& Cavus, 2019). The most common thermoplastic polymers used in wood plastic composites are polypropylene (PP), polyethylene (PE), polyvinyl chloride (PVC), and polystyrene (PS) (Kar, 2016). Especially wood, various industrial and agricultural wastes are used as lignocellulosic materials in WPCs. Several studies were investigated on of utilization such as hemp (Karnani et al., 1997) sisal (Kalaprasad et al., 2003), rice husk (Yang et al., 2005), wood (Shah et al., 2005; Mengeloglu et al., 2007), white straw and corn stalk (Panthapulakkal \& Sain, 2006; Karakus et al., 2010), jute (Sever, 2010) and cotton (Bajwa et al., 2011; Wu et al., 2016) in WPC manufacturing.

The USA, Turkey, Canada and many European countries, having temperate climate, are utilized sugar beet (Figure 1) for manufacturing sugar. During this production, significant amount of sugar beet pulp was generated as a byproduct. This waste is widely used for animal feeding (Rouilly et al., 2006; Anonim, 2013; Anonim, 2014). Sugar beet pulp consists mainly of $75-80 \%$ polysaccharides. Sugar beet pulp has approximately $25 \%$ pectin, $22-24 \%$ cellulose, $30 \%$ hemicelluloses and small amounts of lignin and ash (Sun \& Hughes, 1999; Dinand et al., 1999). This by product might have a potential to be utilized as filler in wood plastic composites (WPC).

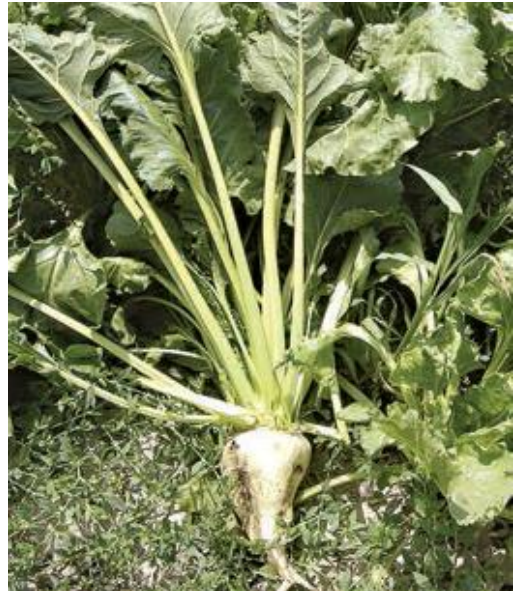

Figure 1. Sugar beet (Beta vulgaris) (Anonim, 2012)

WPC can be manufactured through extrusion, injection and compression molding methods. Extrusion molding methods are mostly used to produce profile type products. Injection molding methods, on the other hand, is generally preferred for the manufacture of complex geometric shape products (Gardner et al., 2015). In the case of compression molding methods, panel like products were manufactured. It is believed that, manufacturing methods have influence on the properties of composite materials.

Previous studies, some properties of composite materials produced with the compression and injection molding methods were investigated using the different thermoplastic and lignocellulosic materials such as wood fiber/PP (Bledzki \& Faruk, 2004), carbon nanotube/PS (Arjmand et al., 2012), silver glass/HDPE (Liu et al., 2017) and wood flour/Polyolefin waste (Basalp et al., 2020).

In this study, sugar beet pulp (SBP) as filler in WPC manufacturing were investigated. The effect of filler and coupling agent content on the properties of SBP/LDPE composites produced using the compression molding method was studied. MAPE was used to ease the compatibility between filler and thermoplastics materials. The physical and mechanical properties of the composites including density, water absorption, thickness swelling, tensile strength, tensile modulus, elongation at break, flexural strength, flexural modulus and impact strength were investigated. 


\section{Material and Method \\ Material}

In the tests, stone pine (Pinus pinea L.) The injection grade of a low density polyethylene (LDPE H2-8) (Petkim Petrochemical company, Turkey) was utilized as a polymermatrix; its density $\left(23^{\circ} \mathrm{C}\right)$, melting temperature and melt flow index $\left(190^{\circ} \mathrm{C}, 2160 \mathrm{~g}\right)$ were 0.919 $\mathrm{g} / \mathrm{cm}^{3}, 110^{\circ} \mathrm{C}$ and $2,4 \mathrm{~g} / 10 \mathrm{~min}$, respectively. Sugar beet pulp (SBP) was obtained from Cumra Sugar Industry (Konya, Turkey) in the form of pellets. SBP were grounded using Wiley mill and sieved into 20-200 (74$840 \mu \mathrm{m})$ mesh size (Figure 2). The mesh size distribution of SBP showed Figure 3. To determine the chemical content of sugar beet pulp, chemical analyzes were conducted according to TAPPI standards and published elsewhere (Karakuset al., 2016). Sugar beet pulp was dried at $103 \pm 2^{\circ} \mathrm{C}$ before manufacturing composites.

Maleic anhydride grafted polyethylene (MAPE) (Licocene PE MA 4351) was supplied by Clariant company. It was used as a coupling agent. It has a density of 0.99 $\mathrm{g} / \mathrm{cm}^{3}$, a drop point of $123^{\circ} \mathrm{C}$, viscosity of $300 \mathrm{mPa}$ s and acid value of $43 \mathrm{mg} \mathrm{KOH} / \mathrm{g}$.

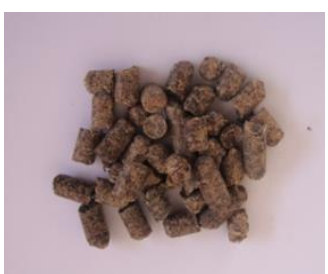

(a)

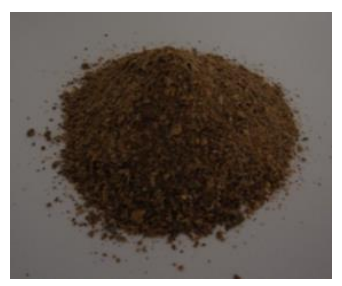

(b)
Figure 2. Sugar beet pulp a) in the form of pellet b) grounded

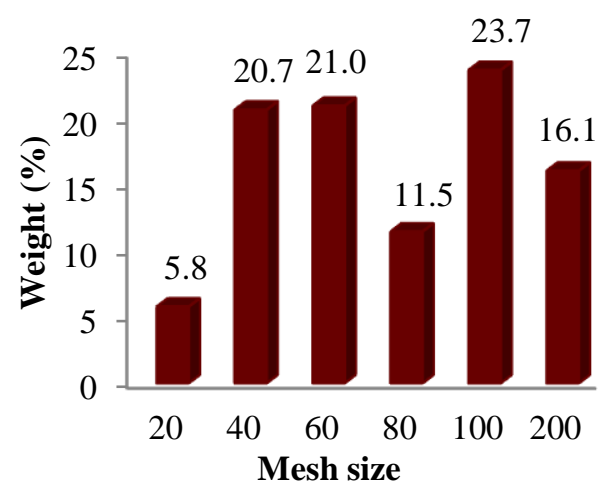

Figure 3. The mesh size distribution of SBP

\section{Preparation of SBP/LDPE Composites}

"Response Surface Methodology" (RSM) was used in the experimental design of SBP/LDPE composites. This experimental design is presented in Table 1. Based on this experimental design, certain amount of polymer (LDPE), filler (SBP), and coupling agent (MAPE) were mixed for $5 \mathrm{~min}$ in a high-speed mixer.

The mixtures were compounded by using a single screw extruder. The extruder barrel temperature from 170 to $200^{\circ} \mathrm{C}$. The screw speed was set at $40 \mathrm{rpm}$. Extruded composites were cooled in water. The cooled composite samples were grounded into pellets. These pellets were dried in the oven at $100^{\circ} \mathrm{C}$ for $24 \mathrm{~h}$. Then, pellets were compression molded using Carver hot press with $175^{\circ} \mathrm{C}$ temperature and $1140 \mathrm{kPa}$ pressure for $10 \mathrm{~min}$ pressing time. Before testing, manufactured specimens were conditioned in a climatic cabin having $20^{\circ} \mathrm{C}$ temperature and $65 \%$ relative humidity.

Table 1. Experimental design of SBP/LDPE composites

\begin{tabular}{cccc}
\hline $\begin{array}{c}\text { Specimen } \\
\text { Code }\end{array}$ & $\begin{array}{c}\text { SBP } \\
(\%)\end{array}$ & $\begin{array}{c}\text { LDPE } \\
(\%)\end{array}$ & $\begin{array}{c}\text { MAPE } \\
(\%)\end{array}$ \\
\hline P & 0 & 100 & 0 \\
\hline P-0-2 & 0 & 98 & 2 \\
\hline P-0-4 & 0 & 96 & 4 \\
\hline P-20 & 20 & 80 & 0 \\
\hline P-20-2 & 20 & 78 & 2 \\
\hline P-20-4 & 20 & 76 & 4 \\
\hline P-40 & 40 & 60 & 0 \\
\hline P-40-2 & 40 & 58 & 2 \\
\hline P-40-4 & 40 & 56 & 4 \\
\hline
\end{tabular}

\section{Characterizations}

The density of produced composites was determined according to ASTM D792 (2013) standards with the water displacement technique. The water uptake analyses were conducted based on the ASTM D570 (2010). The composite was immersed in distilled water for about 5 months. Weights and thicknesses of the specimens were taken at the end of immersion time.

The mechanical properties of composites such as tensile strength, flexural strength, and impact strength were determined according 
to ASTM D638 (2010), ASTM D790 (2010), and ASTM D256 (2010), respectively. The tensile and flexural property tests were conducted using Zwick/Roell Z010 Universal Testing Machine with $10 \mathrm{kN}$ load-cell. Meanwhile, the Izod impact test was carried out by using a Zwick HIT5.5 P Machine and the notches were made with a PolytestRayRan notching cutter. For each property, five specimens were tested and used for analysis. "Design Expert ${ }^{\circledR}$ Version 7.0.3" statistics program was used for data analysis of the composite materials.

\section{Results and Discussion}

Physical properties of SBP/LDPE composites

Density graph of SBP/LDPE composites is shown in Figure 4. Density values of composites were in the range of 0.91-1.02. $\mathrm{g} / \mathrm{cm}^{3}$. In composites, density values were increased with the rising of SBP amount. The addition of MAPE which provide compatibility between polymer and lignocellulosic material was caused to slightly increase density of the samples.

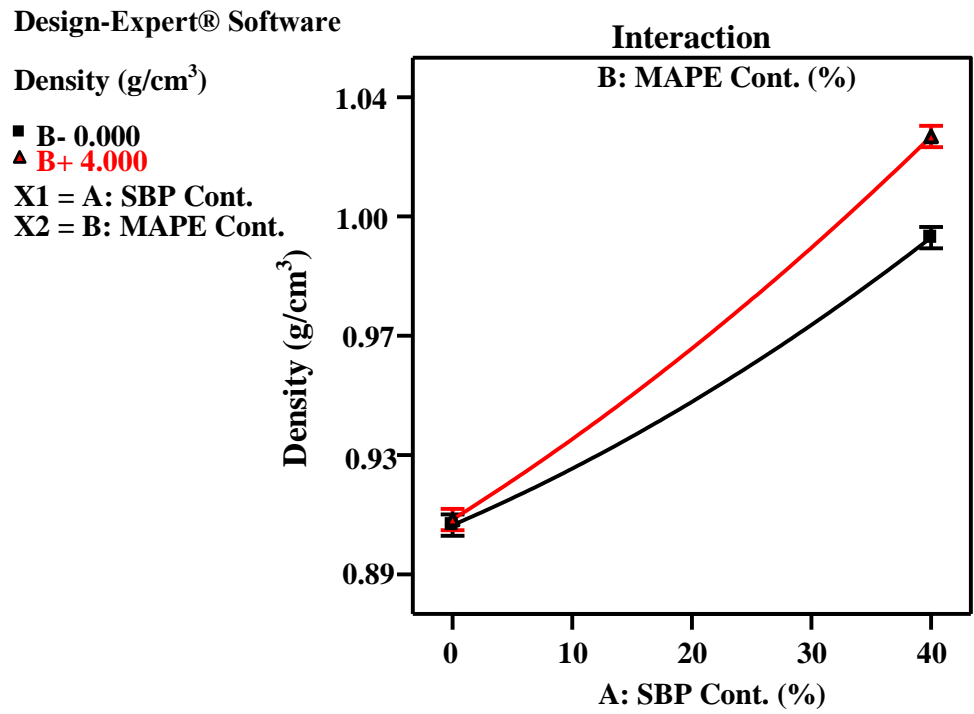

Figure 4. Interaction graph of density values in SBP/LDPE composites

Polymer materials are hydrophobic materials and have limited water absorption capacity. Lignocellulosic materials, on the other hand, are hydrophilic that's why they exchange water depending on the relative humidity of their surroundings. Water absorption (WAt) and thickness swelling (TS) analysis in composite materials were performed on samples containing $40 \%$ lignocellulosic materials.

The water absorption graph (WAt- $\sqrt{t}$ ) of the composites based on the Fickian theory model for a duration of 150 days $(3600 \mathrm{~h}$ ) aging is given in Figure 5. As seen in the figure, diffusion rates are different for each composite sample. In composite materials, generally reduction of water absorption was expected when MAPE was utilized in formulations. It has been observed that MAPE added composites were reached maximum water absorption after 160 days $(3600 \mathrm{~h})$ of exposure. However, to be able to reach the equilibrium state, longer water absorption analysis time was needed. For MAPE added composites, the maximum water absorption time is 3600 hours, and the maximum water absorption percentage is $14.58 \%$. The water absorption still increases up to 3600 hours for composites without MAPE. 


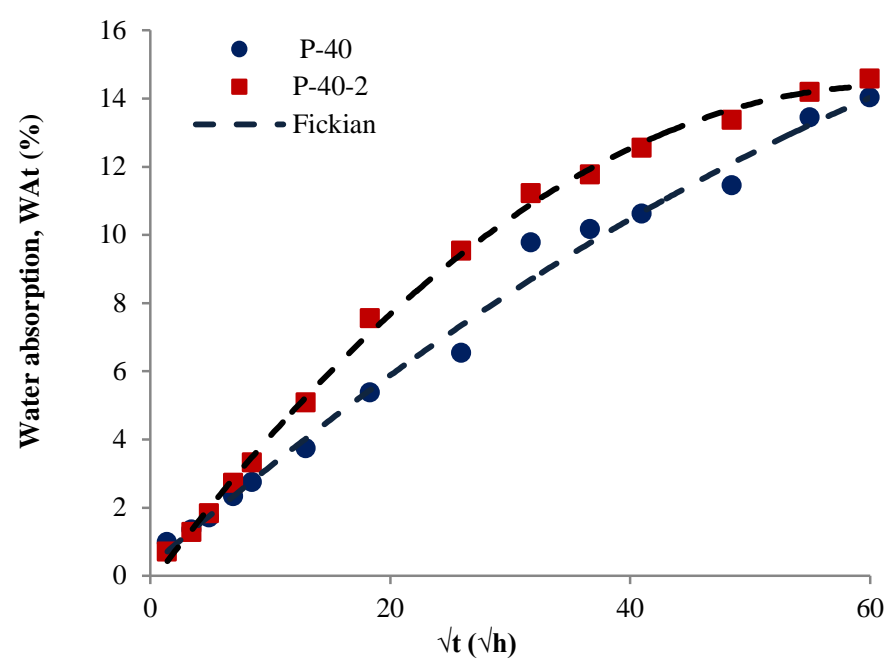

Figure 5. Water absorption graph in SBP/LDPE composites

The Fickian diffusion behavior was observed for the composites having MAPE in formulations. The initially water absorption amount of the samples was rapidly increased and then gradually slowed down until reaching the maximum water absorption values (Aziz et al., 2020). To understand the water absorption behavior of the produced

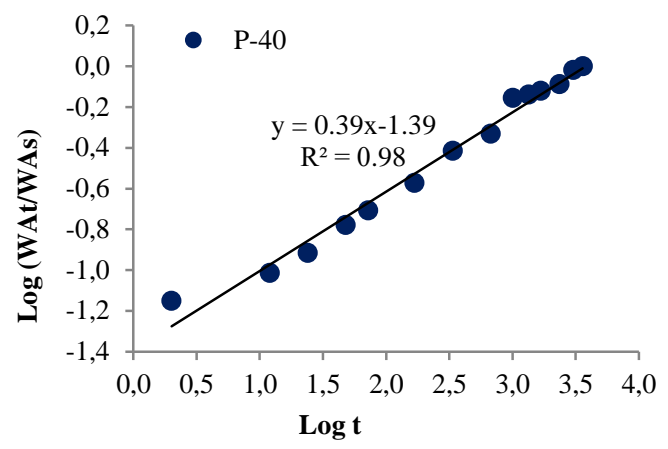

(a) composite materials, the diffusion theory was applied. For this purpose, $\mathrm{n}$ and $\mathrm{k}$ coefficient values were determined from the linear section of $\log$ WAt/WAs-log t graph (Figure 6). Table 2 shows $n$ and $k$ coefficient values. They were used to check whether the water absorption behavior fits the Fickian or nonFickian law.

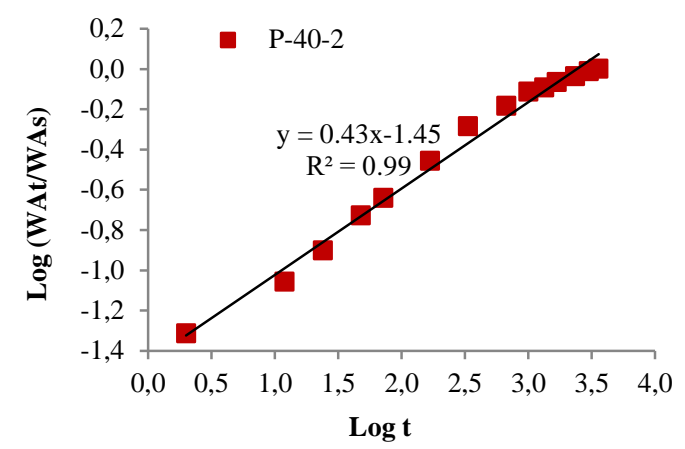

(b)

Figure 6. Diffusion curve of composites a) P-40, b) P-40-2, where $y=\log$ WAt/WAs, $x=\log t, R^{2}$ is the coefficient of correlation

According to Table 2, the $\mathrm{n}$ value for $\mathrm{P}-40$ is 0.38 and for P-40-2 is 0.42 . The fact that the value of $\mathrm{n}$ is less than 0.5 indicates that the diffusion of the water was differed slightly from the normal Fickian behavior and thus it can be evaluated as anomalous (Adhikary et al., 2008; Ahmad et al., 2010).
In order to verify the Fickian behavior, the WAt/WAs- $\sqrt{t}$ graphs of composites were investigated (Figure 7). In both composite samples, it seems that the graph remains linear up to WAt $=0.6$ WAs. Consequently, it was confirmed that composites follow the Fickian behavior. 


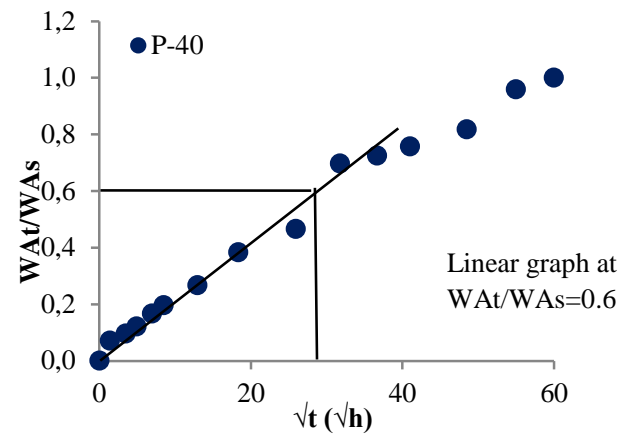

(a)

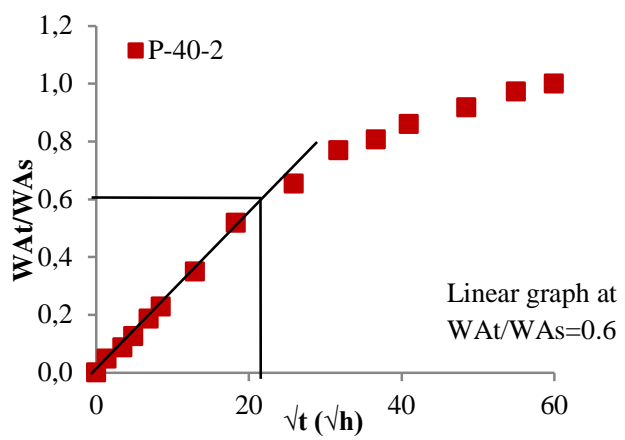

(b)

Figure 7. Plotted curves to check for Fickian behavior of composites a) P-40, b) P-40-2

The thickness swelling graph of the composites is given in Figure 8. Both composite samples showed a similar trend in thickness swelling behavior. It has been observed that samples were reached maximum thickness swelling after 126 days (3024 hours) exposure. The maximum thickness swelling percentage for composites without MAPE is $9.4 \%$ while for MAPE added composites is $9.9 \%$.

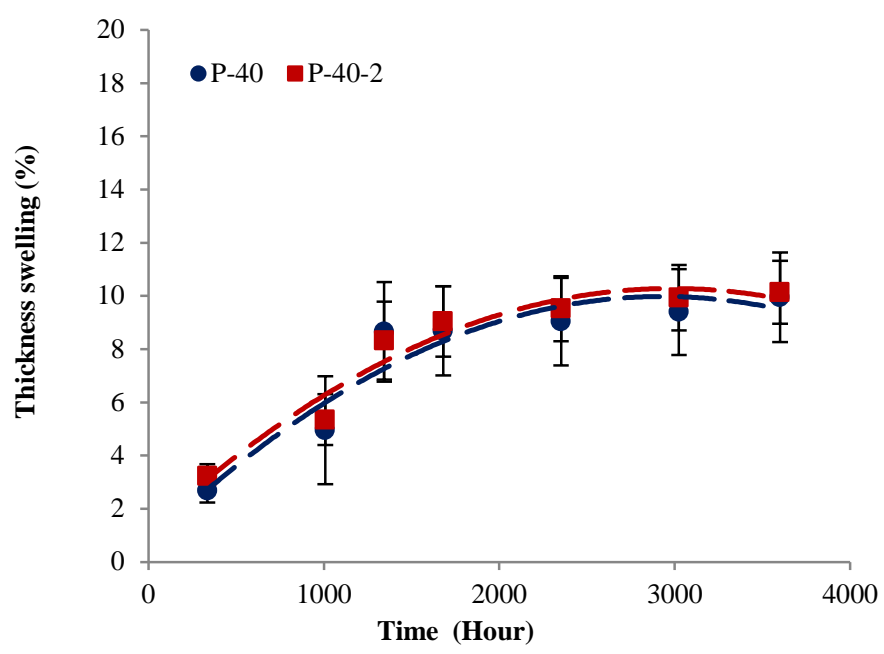

Figure 8. Thicknes sswelling graph in SBP/LDPE composites

Table 2. Diffusion behavior based on $n$ coefficient values, where WAt/WAs $=k t n$, WAt represents the water absorption at time, WAs refers to the water absorption at equilibrium saturation, $\mathrm{k}$ is a constant that depends on the structural characteristics of th the mode of transport

\begin{tabular}{cccccc}
\hline \multirow{2}{*}{ Specimen Code } & \multicolumn{2}{c}{ WAt/WAs $=\mathrm{kt}^{\mathrm{n}}$} & & WAt/WAs=0.6 & Fickian or \\
\cline { 2 - 3 } & $\mathrm{n}$ & $\mathrm{k}$ & & & Non-Fickian \\
\hline P-40 & 0.39 & -1.39 & & Yes & Fickian \\
P-40-2 & 0.43 & -1.45 & & Yes & Fickian \\
\hline
\end{tabular}

\section{Mechanical Properties of SBP/LDPE Composites}

Tensile properties of the LDPE based composites such as tensile strength, tensile modulus, and elongation at break were determined (Fig. 9). Tensile strength values of composite materials were in the range of 5.6-8.8MPa. In composites, reduction of tensile strength values with increased SBP amount was observed. It is believed that incompatibility between hydrophobic LDPE and hydrophilic SBP was resulted in this reduction. In our previous study, similar trend was also observed for injection molded samples (Karakus et al., 2016). It was noted that the samples produced with injection 
molded have better tensile strength values than the compression molded samples due to providing the homogeneous distribution of fillers in matrix (Bledzki \& Faruk, 2004; Liu et al., 2017). The tensile strength values were improved with MAPE coupling agent due to the improved compatibility of the matrix and filler. With the addition of MAPE, tensile strength values were increased linearly. MAPE is well known as an effective interfacial adhesion agent (Yang et al., 2007; Tasdemir et al., 2009; Liu et al., 2017; Cavus \& Mengeloglu, 2019). Tensile modulus values in the range of $94.8-222.7 \mathrm{MPa}$ in composite samples. It was observed that the lignocellulosicfiller has a significant effect on the tensile modulus of composite samples. With the increase in SBP amount, the tensile modulus values were increased. This increase can be explained by the rule of mixture. The

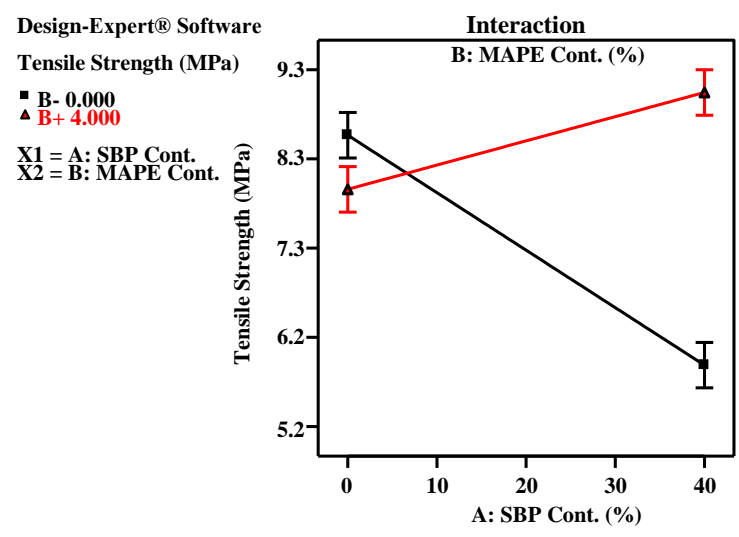

(a) tensile modulus of the lignocellulosic filler is higher than the tensile modulus of the plastic itself. For this reason, the tensile modulus was increased with the rise of SBP amount (Brahmakumar et al., 2005; Mengeloglu \& Karakus, 2008). The tensile modulus values were also improved with the MAPE addition to the composite materials.

Elongation at break values between 4.9 and $208.7 \%$ in composites. The interaction graph of elongation at break values of composites is presented in Figures 9c. The elongation at break values was decreased with the rising of SBP amount. Adding lignocellulosic fillers into the polymer matrix creates a more fragile structure. Due to this fragile structure, elongation at break values were decreased (Brahmakumar et al., 2005). In addition, elongation at break values was decreased with the addition of MAPE.

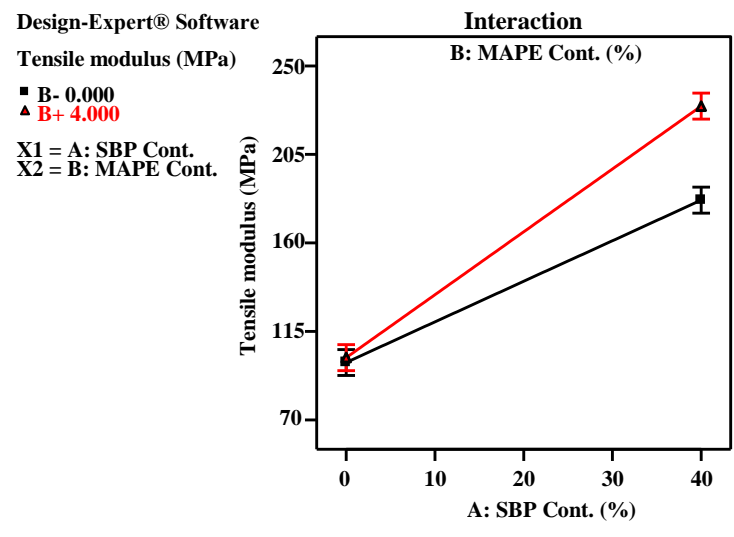

(b)

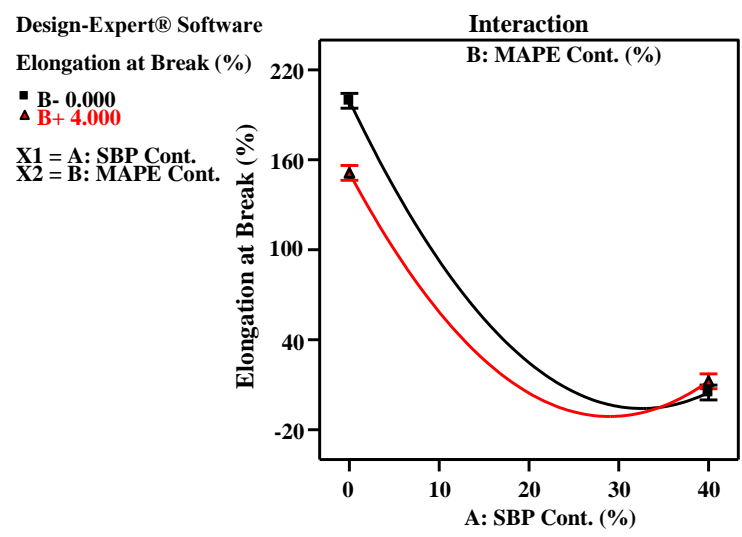

(c)

Figure 9. Interaction graphs of tensile properties in SBP/LDPE composites, a) tensile strength, b) tensile modulus, c) elongation at break 
The flexural strength values of the composites were in the range of 6.7-15.7 $\mathrm{MPa}$. Interaction graphs of flexural strength values of composites are shown in Figure 10a. It has been determined that increase of SBP was created a positive effect on the flexural strength values. Adding MAPE to composite materials were also improved the values. Similar results were also reported by others (Liu \& Wang, 2017; Tisserat et al., 2017; Huang et al., 2018; Cavus \& Mengeloglu, 2020). Flexural modulus values of composites

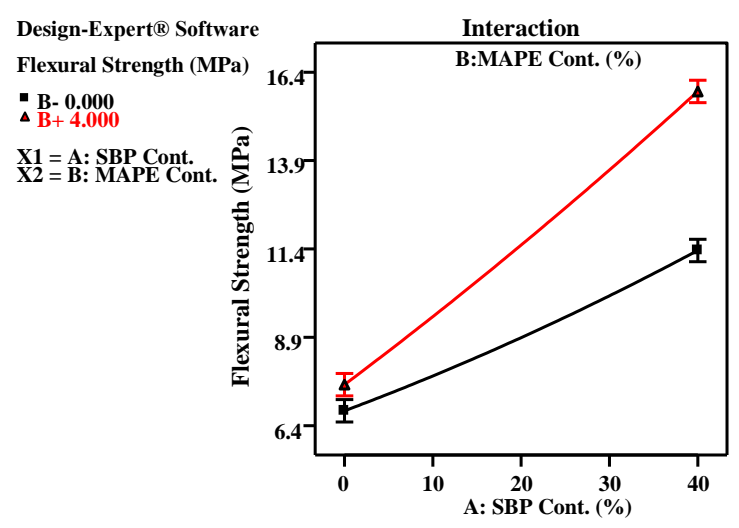

(a) were in the range of 179.6-576.3 $\mathrm{MPa}$ (Figure 10b). Flexural modulus of composites was improved with the both rising percentage of SBP and MAPE amount. Flexural strength values of the manufactured composites are higher than required value of 6.9 MPa by the ASTM D 6662 (2013) standards. In the case of flexural modulus, only composites having $40 \%$ SBP has passed the required standard values of $344.4 \mathrm{MPa}$. According to these results, it is confirmed that SBP/LDPE composites can be used in the plastic lumber applications.

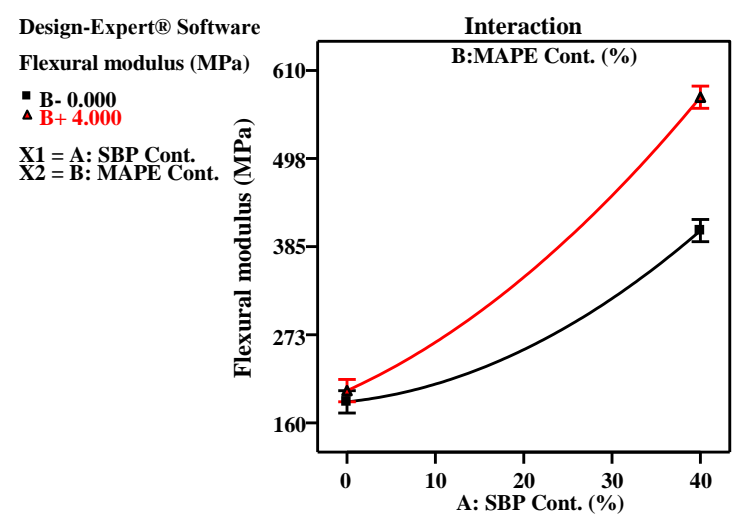

(b)

Figure 10. Interaction graphs of flexural properties in SBP/LDPE composites, a) flexural strength, b) flexural modulus

The Izod impact strength values are between 4.0 and $38.9 \mathrm{~kJ} / \mathrm{m}^{2}$ in composites. When the impact strength graph of composites is examined (Figure 11), impact strength values was reduced with the increase of SBP amount. It has been observed that addition of MAPE as a coupling agent has a negative effect on the impact strength values of composites. This negative effect was also reported by others (Mengeloglu \&Karakus, 2008; Tasdemir et al., 2009).

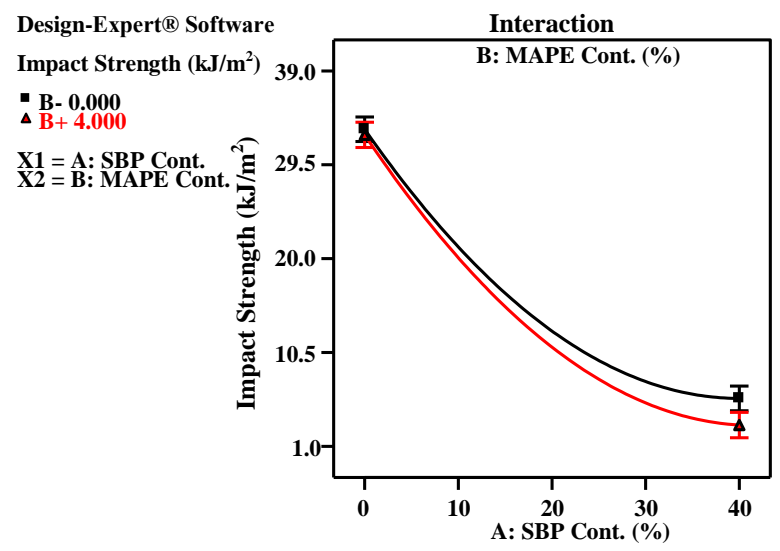

Figure 11. Interaction graph of impact strength values in SBP/LDPE composites 


\section{Conclusions}

In this study, SBP/LDPE composites were produced using compression molding process. The physical and mechanical properties of the produced composites were determined. Following conclusions were driven;

Sugar beet pulp (SBP) can be successfully used as an alternative lignocellulosic filler in the wood plastic composite production.

The density, flexural strength, flexural modulus, and tensile modulus were increased with the rising concentration of SBP in composites but tensile strength, impact strength, and elongation at break were reduced.

The use of MAPE coupling agent has improved strength and modulus properties in the expense of reduced impact strength and elongation at break values. In addition, MAPE utilization had no significant effect on water uptake and thickness swelling values.

\section{Acknowledgements}

This research was financially supported by the Scientific Research Project Fund of Kahramanmaras Sutcu Imam University (Project Number: 2014/1-22YLS).

\section{Ethics Committee Approval N/A}

\section{Peer-review}

Externally peer-reviewed.

\section{Author Contributions}

Conceptualization: Y.B., K.K., F.M.; Investigation: Y.B., K.K., F.M.; Material and Methodology: Y.B., F.M.; Supervision: F.M.; Visualization: Y.B.; Writing-Original Draft: Y.B.; Writing-review \& Editing: Y.B., K.K., F.M.; Other: All authors have read and agreed to the published version of manuscript.

\section{Conflict of Interest}

The authors have no conflicts of interest to declare.

\section{Funding}

This study has been supported within the scope of project numbered 2014/1-22YLS by Kahramanmaras Sutcu Imam University,
Scientific Research Project Coordination Department.

\section{References}

Adhikary, K. B., Pang, S. \& Staiger, M. P. (2008). Long-term moisture absorption and thickness swelling behaviour of recycled thermoplastics reinforced with Pinusradiata sawdust. Chemical Engineering Journal, 142(2), 190-198.

Ahmad, Z., Ansell, M. P. \& Smedley, D. (2010). Effect of nano-and micro-particle additions on moisture absorption in thixotropic room temperature cure epoxy-based adhesives for bonded-in timber connections. International Journal of Adhesion and Adhesives, 30(6), 448-455.

Anonim. Konya Şeker A.Ş. Bitkisel Üretim Çiftçi Rehberi (2012).

Anonim. T.C., Şeker Kurumu. 2012 yılı Faaliyet Raporu, (2013).

Anonim. Türkiye Şeker Fabrikaları A.Ş. Sektör Raporu (2013), (2014).

Arjmand, M., Apperley, T., Okoniewski, M. \& Sundararaj, U., (2012). Comparative study of electromagnetic interference shielding properties of injection molded versus compression molded multi-walled carbon nanotube/polystyrene composites. Carbon, 50(14), 5126-5134.

ASTM D570, (2010). Standard test method for water absorption of plastics. ASTM International.

ASTM D638, (2010). Standard test for tensile properties of plastics. ASTM International.

ASTM D790, (2010). Standard test methods for flexural properties of unreinforced and reinforced plastics and electrical insulating materials. ASTM International.

ASTM D256, (2010). Standard test for determining the Izod pendulum impact resistance of plastics. ASTM International.

ASTM D6662, (2013). Standard specification for polyolefin-based plastic lumber decking boards. ASTM International.

ASTM D792, (2013). Standard test methods for density and specific gravity (relative density) of plastics by displacement. ASTM International.

Aziz, N. F. A., Ahmad, Z. \& Puaad, M. B. F. M. (2020). Study of the behavior of moisture absorption and swelling in high filler loading kenaf core/bast polyethylene composites. Advances in Civil Engineering Materials, 9(1), 250-261.

Basalp, D., Tihminlioglu, F., Sofuoglu, S. C., Inal, F. \& Sofuoglu, A. (2020). Utilization of Municipal Plastic and Wood Waste in 
Industrial Manufacturing of Wood Plastic Composites. Waste and Biomass Valorization, $1-12$.

Bajwa, S. G., Bajwa, D. S., Holt, G., Coffelt, T. \& Nakayama, F. (2011). Properties of thermoplastic composites with cotton and guayule biomass residues as fiber fillers. Industrial Crops and Products, 33(3), 747-755.

Bledzki, A. K. \& Faruk, O. (2004). Wood fiber reinforced polypropylene composites: Compression and injection molding process. Polymer-Plastics Technology and Engineering, 43(3), 871-888.

Brahmakumar, M., Pavithran, C. \& Pillai, R. M. (2005). Coconut fibre reinforced polyethylene composites: effect of natural waxy surface layer of the fibre on fibre/matrix interfacial bonding and strength of composites. Composites Science and Technology, 65(3-4), 563-569.

Cavus, V. \& Mengeloglu, F. (2020). Effect of wood particle size on selected properties of neat and recycled wood polypropylene composites. BioResources, 15(2), 3427-3442.

Dinand, E., Chanzy, H. \& Vignon, R. M. (1999). Suspensions of cellulose microfibrils from sugar beet pulp. Food Hydrocolloids, 13(3), 275-283.

Gardner, D. J., Han, Y. \& Wang, L. (2015). Wood-plastic composite technology. Current Forestry Reports, 1(3), 139-150.

Huang, L., Mu, B., Yi, X., Li, S. \& Wang, Q. (2018). Sustainable use of coffee husks for reinforcing polyethylene composites. Journal of Polymers and the Environment, 26(1), 4858.

Kalaprasad, G., Mathew, G., Pavithran, C. \& Thomas, S. (2003). Melt rheological behavior of intimately mixed short sisal-glass hybrid fiber-reinforced low-density polyethylene composites. I. Untreated fibers. Journal of Applied Polymer Science, 89(2), 432-442.

Karakus, K., Gulec, T., Kaymakci, A., Mengeloglu, F., 2010. Misır sap1 unlarının dolgu maddesi olarak polimer kompozit üretiminde değerlendirilmesi. Ш. Ulusal Karadeniz Ormancilık Kongresi. 20-22 Mayıs, Trabzon. 2013-2019.

Karakus, K., Birbilen, Y. \& Mengeloğlu, F. (2016). Assessment of selected properties of LDPE composites reinforced with sugar beet pulp. Measurement, 88, 137-146.

Kar, K. K. (Ed.). (2016). Composite materials: processing, applications, characterizations. Springer.

Karnani, R., Krishnan, M. \& Narayan, R. (1997). Biofiber-Reinforced

Polypropylene
Composites. Polymer Engineering and Science, 37(2), 476-482.

Liu, B., Jin, Y. \& Wang, S. (2017). Effect of processing method on the mechanical and thermal of Silvergrass/HDPE composites. In AIP Conference Proceedings (Vol. 1839, No. 1, p. 020002).AIP Publishing LLC.

Mengeloglu, F. \& Cavus, V. (2019). Additives used in wood plastic composite manufacturing. Research and Reviews in Agriculture, Forestry and Aquaculture Sciences, Summer, 49-58.

Mengeloglu, F., Kurt, R., Gardner, D. J., O’Neill, S. (2007). Mechanical Properties of Extruded High-Density Polyethylene and Polypropylene Wood Flour Decking Boards. Iranian Polymer Journal, 16(7), 477-487.

Mengeloglu, F. \& Karakus, K. (2008). Some properties of eucalyptus wood flour filled recycled high density polyethylene polymercomposites. Turkish Journal of Agriculture and Forestry, 32(6), 537-546.

Panthapulakkal, S. \& Sain, M. (2006). Injection molded wheat straw and corn stem filled polypropylene composites. Journal of Polymers and the Environment, 14(3), 265272.

Petkim, PetrokimyasalMaddeleriÜretimZinciri, PetkimAraştırmaMerkezi, (2019).

https://app.petkim.com.tr/web/urun/File.ashx?fn= UR.12-BF-U1221\&l=tr\&fl=urunler Accessed 20.04.2020.

Rouilly, A., Jorda, J. \& Rigal, L. (2006). Thermomechanical processing of sugar beet pulp. I. Twin-screw extrusion process. Carbohydrate polymers, 66(1), 81-87.

Shah, B. L., Matuana, L. M. \& Heiden, P. A. (2005). Novel coupling agents for PVC/woodflour composites. Journal of Vinyl and Additive Technology, 11(4), 160-165.

Sever, K. (2010). The improvement of mechanical properties of jute fiber/LDPE composites by fiber surface treatment. Journal of reinforced plastics and composites, 29(13), 1921-1929.

Sun, R. C. \& Hughes, S. (1999). Fractional isolation and physico-chemical characterization of alkali-soluble polysaccharides from sugar beet pulp. Carbohydrate Polymers, 38(3), 273-281.

Tasdemir, M., Biltekin, H. \& Caneba, G. T. (2009). Preparation and characterization of LDPE and PP-wood fiber composites. Journal of applied polymer science, 112(5), 3095-3102.

Tisserat, B. H., Reifschneider, L., Gravett, A. \& Peterson, S. C. (2017). Wood-plastic composites utilizing wood flours derived from 
fast-growing trees common to the Midwest. BioResources, 12(4), 7898-7916.

Wu, H., Liang, X., Huang, L., Xie, Y., Tan, S. \& Cai, X. (2016). The utilization of cotton stalk bark to reinforce the mechanical and thermal properties of bio-flour plastic composites. Construction and Building Materials, 118, 337-343.

Yang, H. S., Wolcott, M. P., Kim, H. S. \& Kim, H. J. (2005). Thermal properties of lignocellulosic filler-thermoplastic polymer bio-composites. Journal of Thermal Analysis and Calorimetry, 82(1), 157-160.

Yang, H. ., Wolcott, M. P., Kim, H. S., Kim, S., Kim, H. J. (2007). Effect of different compatibilizing agents on the mechanical properties of lignocellulosic material filled polyethylene bio-composites. Composite Structures, 79, 369-375. 